\title{
Constructing habitat for a sustainable native fisheries in the Sphinx Lake end pit lake system
}

\author{
C.J. Brinker Silkstone Environmental Ltd, Canada \\ M.D. Symbaluk Teck Resources Limited, Canada \\ J.G. Boorman Pisces Environmental Consulting Services Ltd., Canada
}

\begin{abstract}
Fisheries habitat and watershed integrity are highly valued resources in the subalpine natural subregion of west-central Alberta. Teck's Luscar open pit coal mine has been in operation in this area since 1969, and 51-C6 pit was mined from 1992 to 1999. Accomplishing a sound development and reclamation plan to meet biodiversity objectives for 51-C6 pit included operational considerations such as surface water diversions and post-mining fisheries habitat development. The pit had to be mined and reclaimed such that the end pit and inlet/outlet streams would sustain in perpetuity the full range of habitat and watershed features needed to support native Athabasca Rainbow Trout (Oncorhynchus mykiss) and Bull Trout (Salvelinus confluentus).

The five year post-reclamation fisheries habitat and population assessment indicates a surging Rainbow Trout population, high growth rates and enhanced habitat conditions as compared with the pre-mine coldwater, lotic system. This paper covers the process from environmental assessment through construction and reclamation to closure assessment, highlighting the challenges, uncertainties, and successes of Teck's award-winning Sphinx Lake system within the context of biological diversity.
\end{abstract}

\section{Introduction}

Cardinal River Operations (CRO) is one of six Teck open pit coal mining operations in western Canada. The Luscar Mine is one of two mines operated by CRO. Coal mining has been conducted over the past 100 years in this region and, at CRO's operations, produces a high-quality bituminous metallurgical coal for the global seaborne market for steel production.

Over 25 mine pits have been developed at the Luscar Mine since its inception in 1969. End pit lakes have been developed in several of those pits as part of the mine's reclamation plan. The reclamation of mine pits as lakes has been the subject of some recent deliberation in Alberta, culminating in government/industry recommendations and guidelines for the development of pit lakes issued by the End Pit Lake Working Group (EPLWG, 2003). The primary objective of these guidelines is the development of a self sustaining salmonid sport fishery.

The 51-C6 Pit is in the Sphinx Creek drainage and is one of those developments requiring the reestablishment of fisheries habitat of equivalent productivity to the pre-disturbance condition. The aquatic component of the reclamation plan for this development is the focus of this paper.

\section{Environmental setting}

Cardinal River Operations are located in the subalpine natural subregion (Beckingham et al., 1996) of the Rocky Mountains, south of Hinton, Alberta. Elevation ranges from 1,450-1,900 m and topography is steeply rolling. Geological strata consist of uplifted Mesozoic shales and sandstones; acid generation potential is low. Parent materials are commonly shallow to moderate morainal, colluvial and fluvial, underlain by bedrock. Soils are dominantly Brunisols and Regosols.

Vegetation is primarily successionally mature coniferous forest consisting of lodgepole pine and white Engelmann spruce with understory consisting of grasses, forbs, mosses and ericaceous shrubs. The climate includes short, cool summers and long, cold winters modified by short periods of Chinook conditions. 
Precipitation averages $650 \mathrm{~mm}$ annually, most of which falls as rain from May through July. Extreme winds occur frequently, particularly in winter months.

The hydrology of Sphinx Creek is typical of east-slopes streams - cold, high energy, subject to wide fluctuations in stream flow with the lowest flows occurring in winter and peak flows during spring freshet and in quick response to often intense summer storm events. Sphinx Creek above the pit lake drains $21.8 \mathrm{~km}^{2}$ of mountainous terrain.

Sphinx Creek supports resident and migratory native populations of Athabasca Rainbow Trout (Oncorhynchus mykiss) and Bull Trout (Salvelinus confluentus). Mountain Whitefish (Prosopium williamsoni) and Brook Trout (Salvelinus fontinalis, an introduced species) are also present further down in the Gregg River watershed but not in Sphinx Creek (J. Allan, pers. comm., 2008).

\section{$3 \quad$ Mining and construction}

Mining in the 51-C6 pit development began in 1992 and was completed in 1998. This pit is at the end of the "51-C Baseline" series of pits and the opportunity for backfilling in the last part of this pit was limited. The pit development footprint occupied 45 ha and the deepest part of the pit was $65 \mathrm{~m}$. Much of this was backfilled with waste rock, leaving a residual pit area of 6.4 ha, maximum depth of $50 \mathrm{~m}$, with high-walls and foot-walls on 2 of 4 sides at an over-all angle of $37^{\circ}$. The remaining two sides consisted of backfill. The mining footprint of this pit over-laps the Sphinx Creek channel and, prior to development, the creek was diverted around the pit in a large diameter culvert.

Reclamation work proceeded in the lake area through these steps:

1. Partial pit dewatering - from 1998 to 2005 , since the pit had slowly filled with water from run-off in the regional watershed and groundwater inflow. Prior to littoral zone work it had to be pumped down below the designed outflow elevation to access the shoreline.

2. Recontouring and soil placement on the slopes surrounding the lake site. Waste rock was sloped at $23-25^{\circ}$ to $3 \mathrm{~m}$ below designed final lake elevation.

3. Littoral zone (lake bottom less than $3 \mathrm{~m}$ depth under final water-line) was constructed. The targeted area of littoral zone was $25 \%$ of the lake area. This required the additional modification of pit ramps and backfill areas. After initial sloping, soil was placed in the littoral zone to provide a suitable substrate for aquatic plant establishment.

4. Habitat construction in the littoral zone - placement of rock piles, island construction and placement of woody material.

5. Outlet channel construction involved the temporary diversion of $100 \mathrm{~m}$ of existing stream channel to permit construction of the final outlet channel.

6. Inlet channel construction required the temporary diversion of $350 \mathrm{~m}$ of existing inlet stream channel to permit construction of the final inlet channel. The existing channel grade was $3-4 \%$ and the final grade had to be at $7 \%$ with several drop structures in order for the inlet channel to tie into the final lake elevation without creating barriers to upstream fish movement.

7. Lake refilling to final elevation.

8. Flushing the newly constructed inlet and outlet channels to remove sediment without sedimentation of receiving waters.

9. Redirecting Sphinx Creek into the newly constructed channel and lake.

Final reclamation was completed in the fourth quarter of 2005 and the creek was directed into the new channel and lake in January of 2006. Revegetation and reforestation of upland areas continued in spring of 2006 and 2007, and is now complete. 


\section{$4 \quad$ Aquatic monitoring programmes}

End pit lake monitoring commitments for lakes developed at CRO's Luscar and Cheviot Mines (CRO, 2005) are derived from recommendations made by the EPLWG (2003). Table 1 (adapted from CRO, 2005) summarises evaluation/performance criteria for the assessment of physical, biological and chemical characteristics of end pit lakes undertaken by Pisces Environmental Consulting Services Ltd. (Pisces).

Table 1 End pit lake monitoring evaluation/performance assessment criteria for select physical, biological and chemical characteristics (adapted from CRO, 2005)

\begin{tabular}{|c|c|c|c|}
\hline Key Issue & Indicator & Parameters & Targets/Goals \\
\hline \multirow[t]{2}{*}{ Physical } & Inlet/outlet stability & $\begin{array}{l}\text { Migration potential to and } \\
\text { from the lake }\end{array}$ & $\begin{array}{l}\text { Accessible; used by fish for } \\
\text { spawning }\end{array}$ \\
\hline & $\begin{array}{l}\text { Sediment yield - erosion } \\
\text { from surrounding land }\end{array}$ & Total suspended solids & $\begin{array}{l}\text { Meet surface water quality } \\
\text { guidelines used in Alberta }\end{array}$ \\
\hline \multirow[t]{2}{*}{ Chemical } & $\begin{array}{l}\text { General water quality; } \\
\text { toxic substances }\end{array}$ & Water chemistry & $\begin{array}{l}\text { Meet surface water quality } \\
\text { guidelines for aquatic life in } \\
\text { Alberta }\end{array}$ \\
\hline & Overturn & $\begin{array}{l}\text { Summer stratification; fall } \\
\text { mixing }\end{array}$ & $\begin{array}{l}\text { Presence of annual summer } \\
\text { stratification and fall overturn }\end{array}$ \\
\hline \multirow[t]{3}{*}{ Biological } & $\begin{array}{l}\text { Biodiversity; } \\
\text { biomass/productivity }\end{array}$ & $\begin{array}{l}\text { Phytoplankton, zooplankton, } \\
\text { benthic invertebrates, fish } \\
\text { species composition }\end{array}$ & Comparable to local lakes. \\
\hline & Game fish production & Annual production & 1 to $1.5 \mathrm{~kg} / \mathrm{ha} / \mathrm{yr}$ \\
\hline & Fish habitat effectiveness & $\begin{array}{l}\text { Diversity of invertebrates; } \\
\text { redds in inlets/outlets }\end{array}$ & $\begin{array}{l}\text { Diversity and abundance of } \\
\text { invertebrates }\end{array}$ \\
\hline
\end{tabular}

End pit lake monitoring programmes have been conducted at the Luscar Mine since the first pit lake was constructed in 1987. The Sphinx system is the first to be monitored against the EPLWG guidelines and the first to follow a systematic long-term programme.

Monitoring of chemical and limnological characteristics of Sphinx Lake was initiated in 2005 (Boorman, 2006), the year prior to outflow, with 4-season chemistry, profile and biological monitoring. In 2007, one year after spilling, an extensive 2-year monitoring programme was initiated. This programme included water chemistry, 4-season profiles, aquatic benthic and macrophyte assessment, and fisheries monitoring which included spawning surveys, population estimates, productivity/biomass estimation, and fish movement patterns. In addition to these focused efforts, Sphinx Creek is one of the streams monitored in CRO's annual fisheries inventory - sites in Sphinx Creek upstream and downstream of the lake have been assessed for fish density since 1995.

\section{$5 \quad$ Aquatic monitoring results}

\subsection{Hydrologic and physical characteristics}

Physical and hydrologic characteristics of the lake system and watershed are summarised in Table 2. A bathymetric drawing with locations of monitoring stations is provided in Figure 1. 
Table 2 Physical and hydrologic characteristics of Sphinx Lake

\begin{tabular}{llll}
\hline Watershed area & $21.8 \mathrm{~km}^{2}$ & Sediment yield & Minimal \\
Lake surface area & $6.4 \mathrm{ha}$ & Shoreline length & $1.06 \mathrm{~km}$ \\
$\begin{array}{l}\text { Typical outlet flow } \\
\text { winter/summer }\end{array}$ & $<0.1 \mathrm{~m}^{3} \mathrm{~s}^{-1}$ (winter), & Lake area $<3 \mathrm{~m}$ depth & $23 \%$ \\
Stability inlet/outlet channels & $0.5-2.0 \mathrm{~m}^{3} \mathrm{~s}^{-1}$ (summer) & & \\
Stability reclaimed slopes & Stable & Lake volume & $802,000 \mathrm{~m}^{3}$ \\
Lake elevation & Stable & Maximum depth & 50 \\
\hline
\end{tabular}

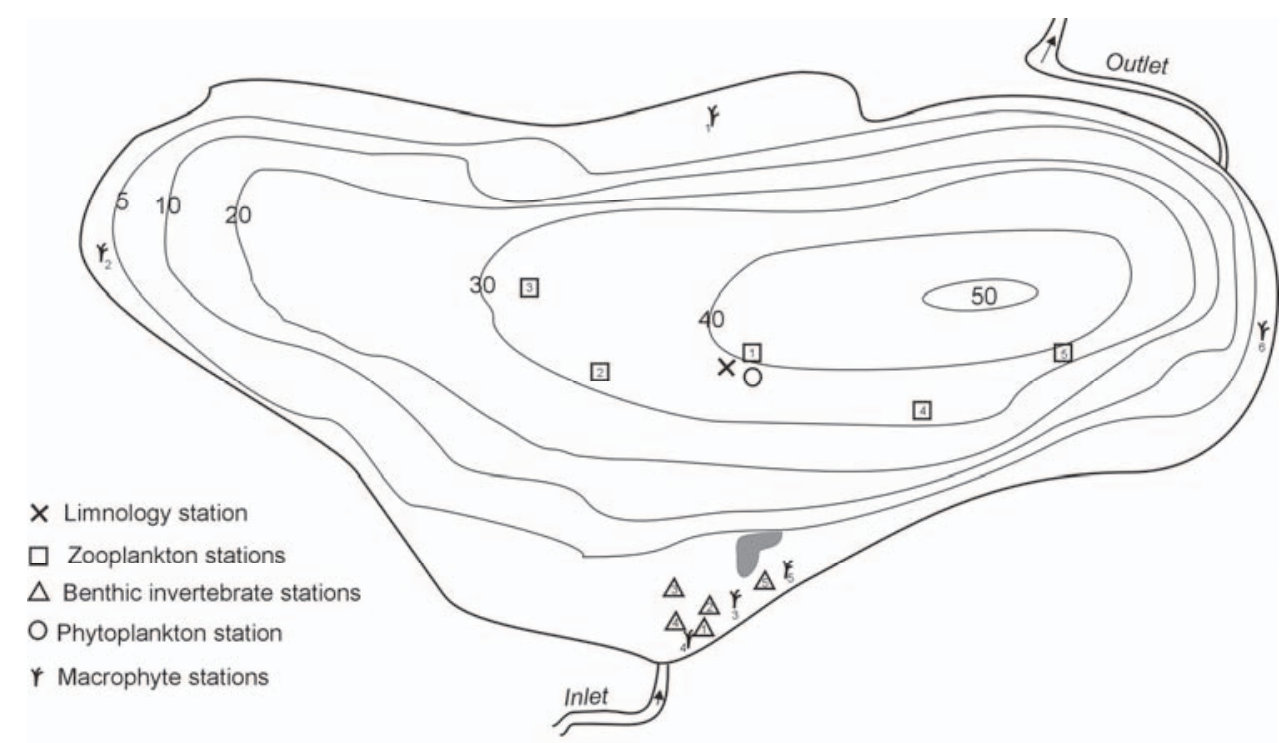

Figure 1 Bathymetric contours (in metres) and monitoring station locations

The inlet and outlet channels have proven to be stable under a range of conditions including a significant flood event that occurred in June of 2007. Surface outflow is continuous from April through October but limited during winter months due to subsurface seepage that re-enters the outlet channel about $50 \mathrm{~m}$ downstream as springs.

\subsection{Basic limnology and water chemistry}

Selected parameters from the aquatic monitoring programme are presented below. The four graphs comprising Figure 2 summarise 4-season temperature and dissolved oxygen profiles and Figure 3 provides electrical conductivity profiles. Temperatures in the inlet and outlet channels are provided in Figure 4.

\subsection{Lower trophic biology and macrophytes}

The planktonic community of Sphinx Lake was examined twice. Phytoplankton counts increased from 315 cells $/ \mathrm{ml}$ in 2005 to 486 cells $/ \mathrm{ml}$ in 2008 and diversity increased from 12 species (or genera, where the plankton was not identified to species level) in 2005 to 23 in 2008. Crustacean zooplankton densities decreased from $2005\left(8,624 / \mathrm{m}^{3}\right)$ to $2008\left(589 / \mathrm{m}^{3}\right)$ and species composition also changed; species diversity remained the same.

Marophytic growth survey in 2005 and again in 2007 found sparse stands of Chara sp. throughout shallow areas of the lake, mostly in the southeast part. Distribution and density increased from 2005 to 2007.

The results of benthic invertebrate sampling conducted in 2008 are summarised in Table 3. 


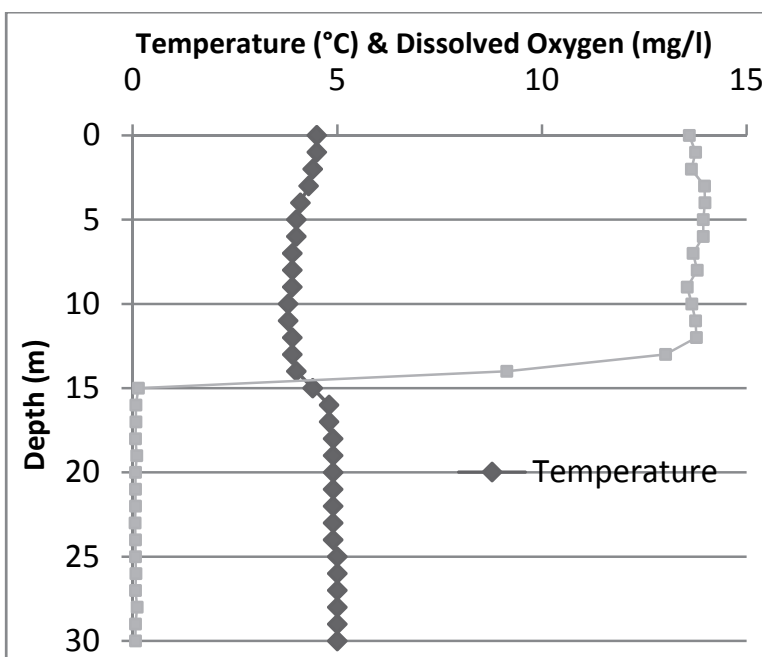

June 13, 2008

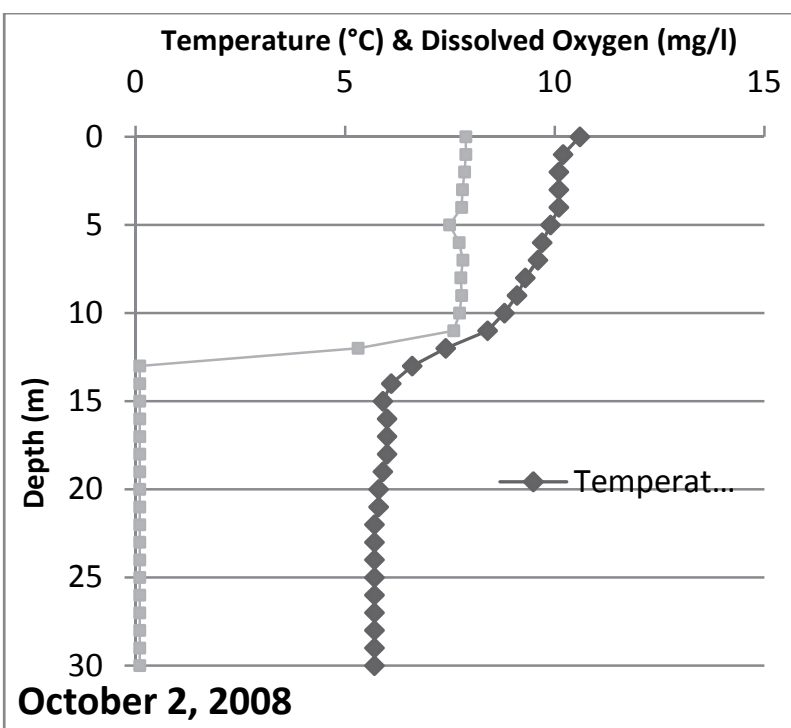

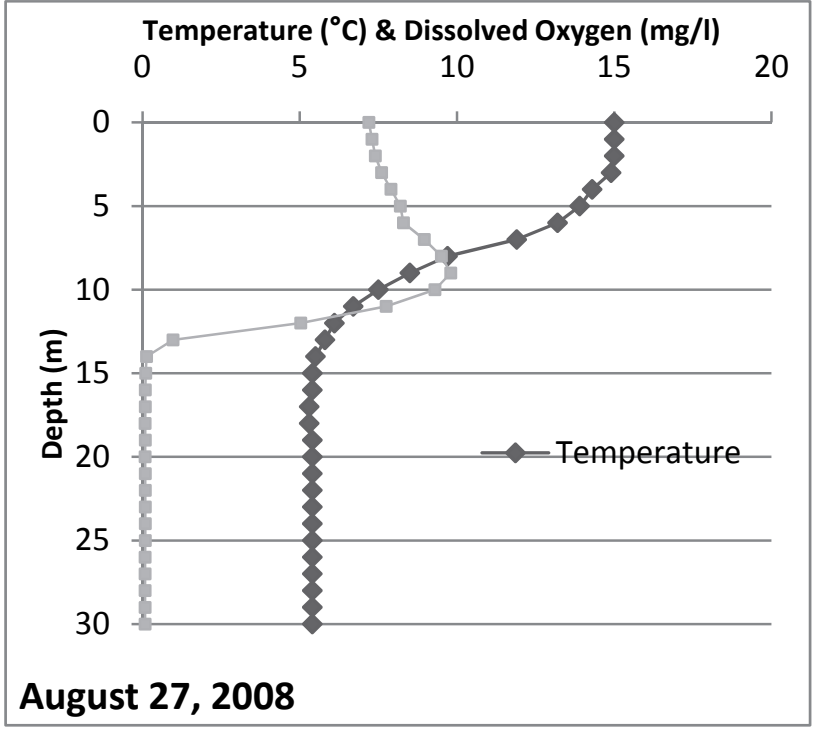

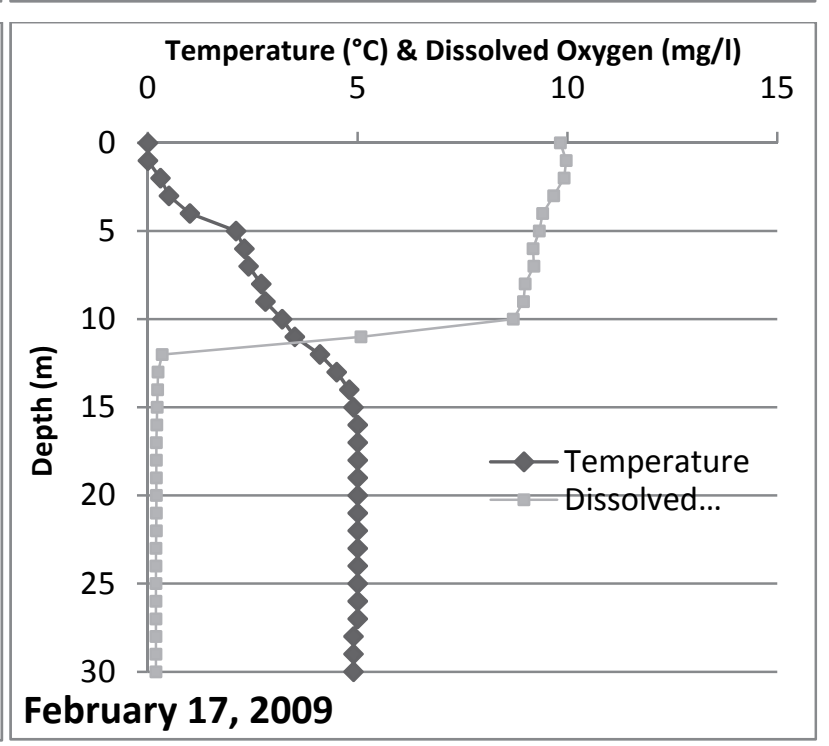

Figure 2 Seasonal temperatures and dissolved oxygen profiles of Sphinx Lake, June 2008 to February 2009

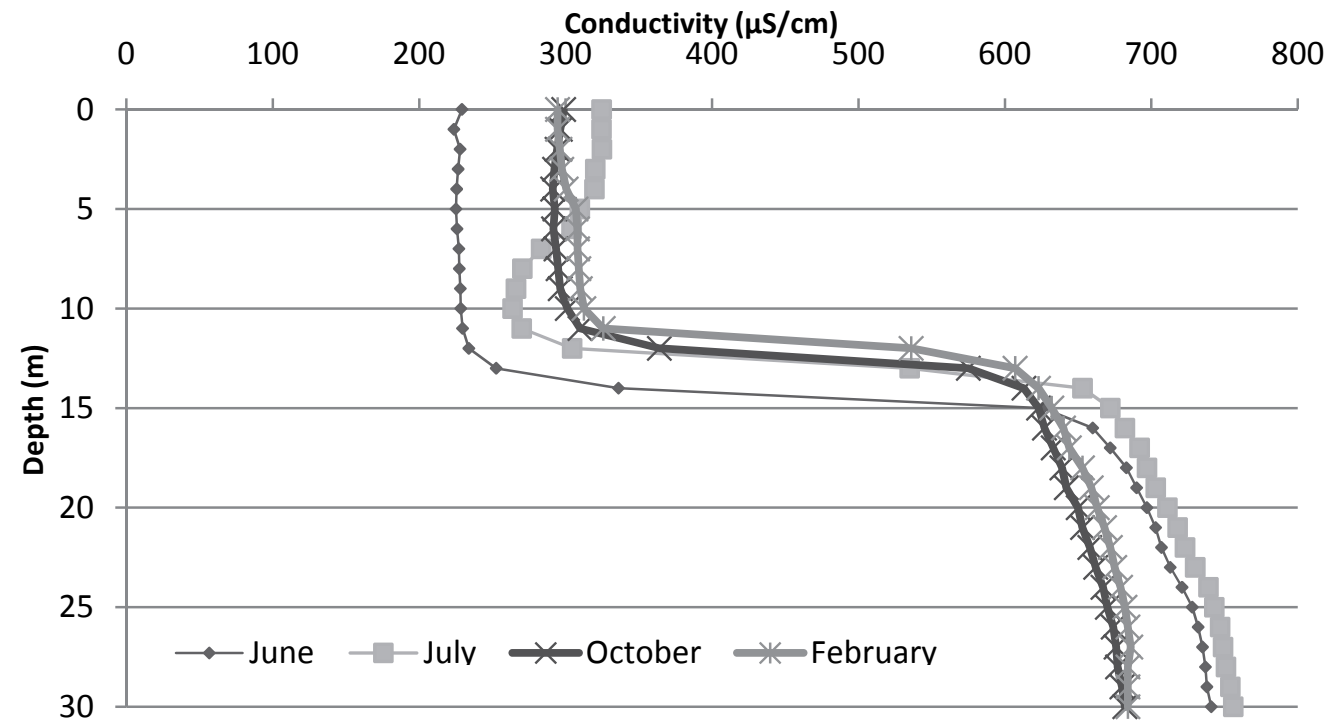

Figure 3 Seasonal conductivity profiles of Sphinx Lake, June 2008 to February 2009 


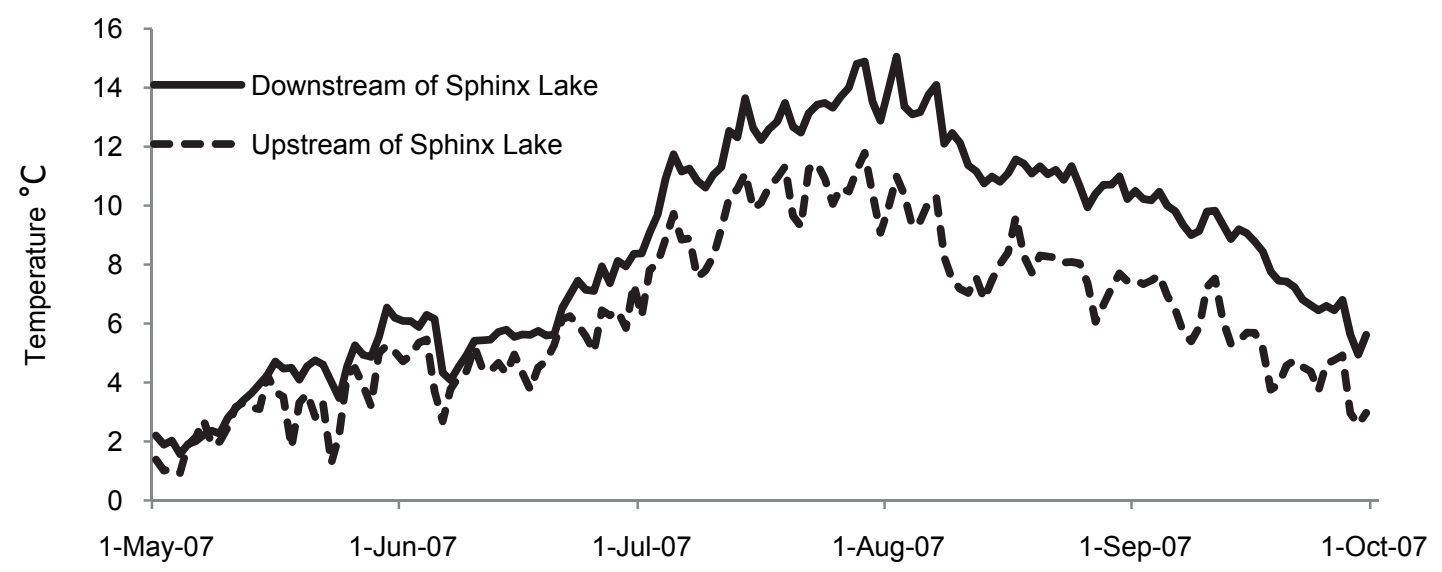

Figure 4 Mean daily water temperature in Sphinx Lake inlet and outlet channels, May-October 2007

Table 3 Benthic invertebrate density in Sphinx Lake, September 2008

\begin{tabular}{lcccccc}
\hline \multirow{2}{*}{ Taxon } & \multicolumn{6}{c}{ Density $\left(\mathbf{n} / \mathbf{m}^{2}\right)$ at Sphinx Lake Sample Sites (SS) } \\
& SS 1 & SS 2 & SS 3 & SS 4 & SS 5 & Mean \\
\hline Trichoptera (caddisflies) & 174 & 0 & 0 & 0 & 0 & 34.8 \\
Coleoptera (beetles) & 174 & 0 & 0 & 0 & 0 & 34.8 \\
Chironomids (midges) & 19,696 & 13,086 & 52,328 & 28,222 & 20,739 & 26,814 \\
Acari (mites and ticks) & 0 & 174 & 0 & 0 & 0 & 34.8 \\
Totals & 20,044 & 13260 & 52,328 & 28,222 & 20,739 & 26,919 \\
\hline
\end{tabular}

\section{$5.4 \quad$ Fisheries}

A two-way fish trap was operated at the outlet channel periodically for 24 days in spring of 2007 and for 80 days from the end of May to mid-October of 2008 to intercept fish moving into and out of the lake. All fish caught in the trap were measured, tagged with Passive Integrated Transponder (PIT) tags and released. Figure 5 summarises size class and movement direction of the fish trapped in 2008. Of the 118 trout trapped in 2008, 38 had been previously tagged in 2006 or 2007 either in Sphinx Lake or in Sphinx Creek downstream of the lake.

Spring spawning surveys were also conducted in the inlet and outlet channels. Several incidents of spawning and/or redds were observed in the outlet channel; none were observed in the inlet channel. 


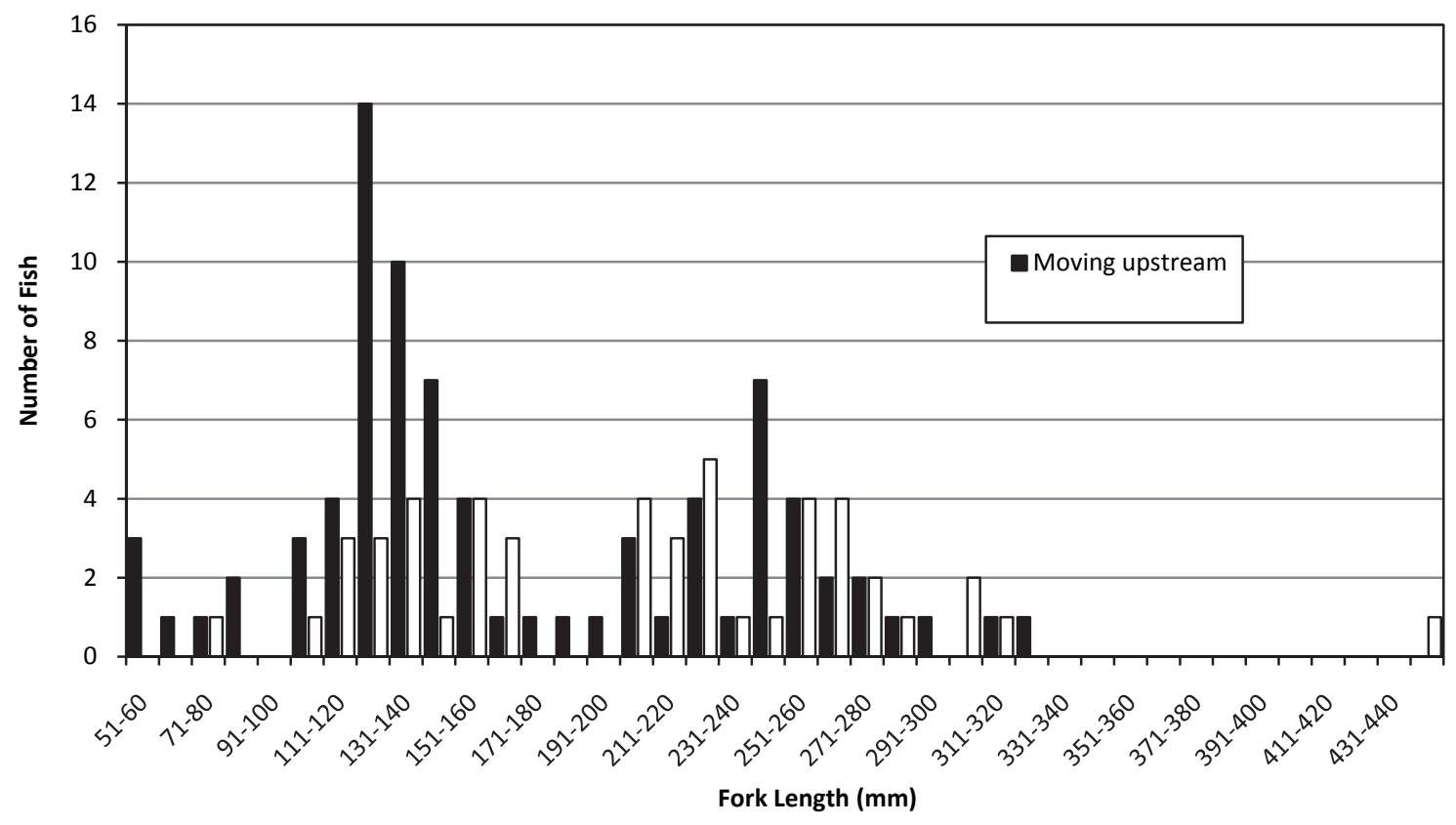

Figure 5 Length class distribution and movement of Rainbow Trout trapped in 2008

Population estimates based on the mark-recapture method were made for the Rainbow Trout cohort $>190 \mathrm{~mm}$ using the Petersen (Ricker, 1975) and CAPTURE (Rexstad and Burnham, 1992) methods. Details of the procedure are described in Pisces, 2009. Two different assumptions regarding the movement of tagged fish into the lake were used to define two marked pools of fish for the purposes of calculating the markrecapture population estimate. Firstly, it was conservatively assumed that the marked pool of fish (Mark Pool 1) consisted only of those marked Rainbow Trout known to have returned to the lake. These fish were either trapped moving upstream into the lake in May and June of 2007 or captured in the lake in October 2007. Secondly, it was assumed that the marked pool of fish (Mark Pool 2) included all Rainbow Trout marked at the fish trap in May and June of 2007 plus those Rainbow Trout marked in the lake in October 2007. In short, all marked fish were presumed to have returned to the lake by time of recapture sampling in 2008. These differing assumptions yielded population estimates of 156 and 195 Rainbow Trout $>190 \mathrm{~mm}$ (Table 4).

Table 4 Population estimates for Rainbow Trout $>190 \mathrm{~mm}$ fork length in Sphinx Lake

\begin{tabular}{lcc}
\hline Method/Assumption & $\begin{array}{c}\text { Population } \\
\text { Estimate }\end{array}$ & $\begin{array}{c}\text { 95\% Confidence } \\
\text { Interval }\end{array}$ \\
\hline CAPTURE/using Marked Pool 1 & 165 & $124-250$ \\
Peterson/using Marked Pool 1 & 156 & $103-271$ \\
CAPTURE/using Marked Pool 2 & 195 & $157-267$ \\
Peterson/using Marked Pool 2 & 194.5 & $146-292$ \\
\hline
\end{tabular}

Annual production estimates, based on population estimates and known annual growth rate, ranged from 1.8 to $3.7 \mathrm{~kg} / \mathrm{ha} /$ year.

In addition to the intensive lake-focused monitoring programme of 2007/08, periodic fisheries inventories have been conducted in Sphinx Creek upstream and downstream of the lake since 1995. Figure 5 summarises population density estimates of Rainbow Trout and Bull Trout in Sphinx Creek below the lake. In 2010, population estimates were not obtained for either species. However, presence/absence survey sampling found both species present and indicated that Rainbow Trout densities remain well above the long-term average. To date, sampling upstream of the lake in the inlet channel indicates considerably lower densities of Rainbow 
Trout than downstream. Sampling also indicates that Bull Trout are relatively more abundant than Rainbow Trout in the inlet channel.

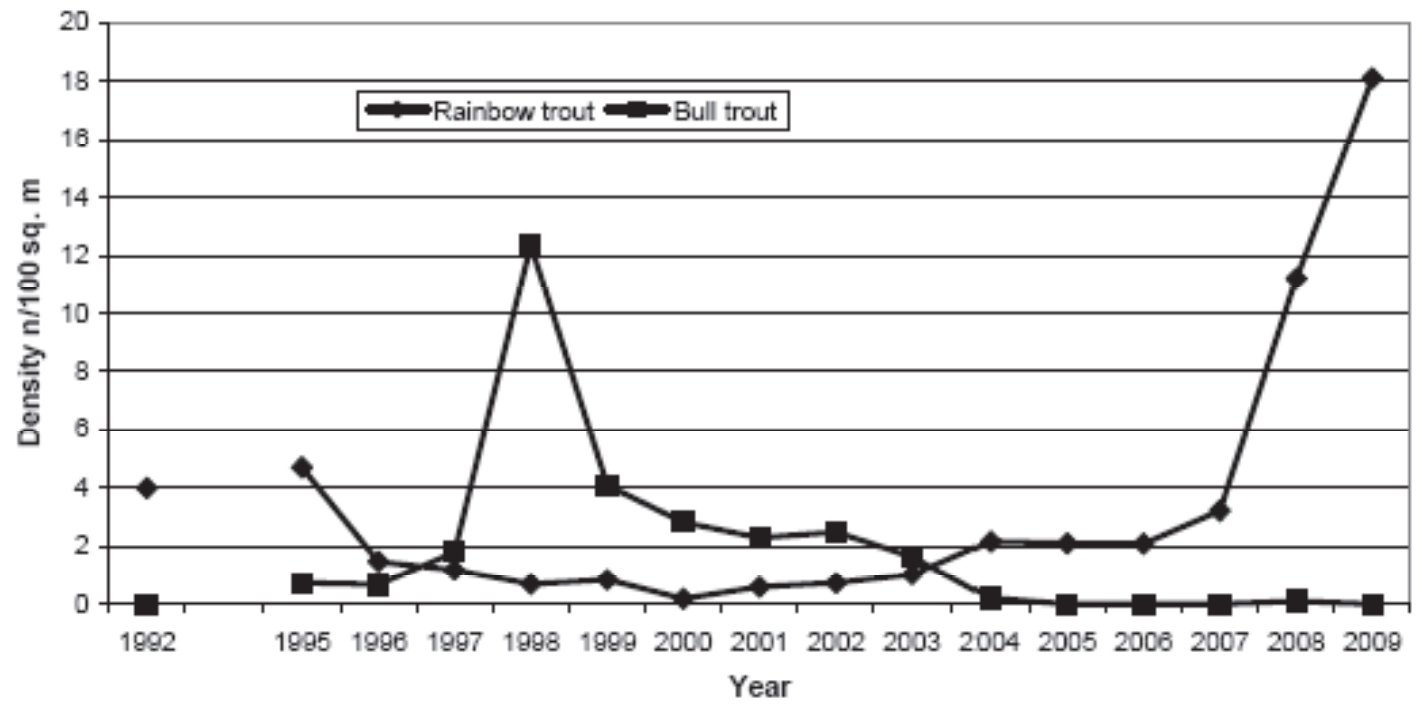

Figure 6 Trout density (one-year and older) estimates for Sphinx Creek below lake

\section{Discussion}

Physical stability: The inlet/outlet channels and lake shoreline are stable and show no signs of significant erosion, even after a significant flood event that occurred in June 2007. Sediment yield from the structures and from the $100+$ ha of reclaimed watershed draining to the lake is negligible, and total suspended solids (TSS) levels in the lake are within provincial standards.

Thermal stratification: The lake is thermally stratified. A chemolimnion is maintained at $10-15 \mathrm{~m}$ in depth and the hypolimnion is consistently at a depth of 14-15 m. No mixing is apparent between the epi- and hypolimnia. These features were consistent between the 2008 and 2005/06 monitoring events. This is analogous to deep, oligotrophic glacial scour lakes that occur naturally in the mountains of Alberta (Mayhood and Anderson, 1976; Thompson, 1978).

Water quality: Concentrations of all water quality parameters decreased between the 2005 and 2008 monitoring events, and concentrations in the epilimnion were consistently less than the hypolimnion. In 2008, all measured parameters for which there are federal guidelines (CCME, 2003) were below those guidelines except for selenium. Selenium ranged from detection limit to $5.9 \mu \mathrm{g} / \mathrm{L}$ (CCME, 2003, guideline is $1.0 \mu \mathrm{g} / \mathrm{L}$ ) and has been trending downward since 2006. Iron and manganese concentrations in the hypolimnion exceeded provincial water quality guidelines (AENV, 1999).

Benthic invertebrates, plankton and macrophytes: Benthic invertebrate densities were high in comparison to other natural lakes in the area. Species diversity was relatively low but within the range of natural variability identified in Mayhood and Anderson (1976). It is expected that species diversity will increase over the next several years as the lake system matures - species diversity increased in Lac des Roches, another end pit lake at the mine, between 1988 and 1991 from 7 to 35 species and density increased six fold in the same period (Schwartz, 2002). Macrophytes are generally scarce or absent in mountain lakes (Anderson, 1971) but where they are present, Chara sp is the dominant species; the increasing trend of Chara sp in Sphinx Lake is consistent with this.

Fisheries: In 2007 and 2008, two to three years after spilling, Sphinx Lake provides habitat for a substantial population of native Athabasca Rainbow Trout, estimated at 23/ha (>190 cm in length), and an annual Rainbow Trout production of $1.89 \mathrm{~kg} / \mathrm{ha}$. Native Bull Trout are also present. The growth rates of Rainbow Trout in the lake are significantly greater than that of rainbows living in the creek upstream or downstream of the lake prior to spilling. This higher growth rate is likely a result of the decreased energy expenditure in the lentic environment, prey availability and warmer water temperature may be associated factors. Densities 
downstream of the lake decreased in 2010 from the peak in 2009 and may be a reflection of natural variation and/or that the spawning population has reached equilibrium with the lake's carrying capacity.

Sphinx Creek downstream of the lake is serving as a spawning and rearing stream for the lake. The high numbers of young-of-year rainbows downstream of the lake in 2008 and 2009 indicate successful spawning. It is common for spring spawning species such as Rainbow Trout to spawn in outlet channels of mountain lakes to take advantage of the warmer spring water temperatures (Mayhood and Anderson, 1976). Pisces, (2008) reported consistently higher spring-time water temperatures in the Sphinx Lake outlet channel than in the inlet.

\section{Conclusions and challenges}

In the five-year period since spilling, the Sphinx Lake system has developed a biotic community that compares favourably with natural, higher-elevation mountain lakes of similar morphometry. End pit lake design guidelines were established for Alberta foothills coal mines in 2003 (EPLWG, 2003). Sphinx Lake meets all of the hydrological, physical and chemical criteria for a successful end pit lake. It is likely that the diversity and biomass of invertebrates and macrophytes will increase over time, similar to other end pit lake experience at the Luscar Mine such as the increase measured in Lac des Roches.

The Rainbow Trout population in this system is robust and capable of supporting a managed sport fishery, but there are a number of challenges that will need to be addressed over the next few years:

1. Recruitment to the lake from Sphinx Creek appears to be high, so that over-recruitment is a possibility that may lead to reduced growth rates. A properly managed fishery could address this issue. The next lake-focussed, intensive monitoring programme is scheduled for 2012/2013 - this will shed light on the long-term sustainability of this system and will support the development of management actions.

2. Selenium concentrations in the system are higher than the federal guideline. Some concern has been raised about the influence of selenium on Rainbow Trout reproduction (Rasmussen et al., 2009). Evidence to date suggests that if selenium is having a negative effect, this is being outweighed by the positive influences of the lentic environment. Future monitoring and the results of research being conducted at the University of Lethbridge may clarify this question.

3. The lack of surface connection in the outlet channel in the winter period is not an ideal situation. Solutions to this are not obvious but will need to be explored, pending the results of future monitoring.

4. Fish movement from the lake into the inlet channel has successfully occurred but is likely limited during periods of low flows. Some of the drop structures may need to be modified to improve upstream fish movement.

\section{Acknowledgements}

We acknowledge the efforts of Jim Allan and Rob Sonnenberg of Pisces Environmental Services Ltd. in providing limnological expertise in the planning and implementation phases of lake construction and in the preparation of this paper. We also acknowledge the invaluable experience and problem-solving resolve of Lindsay Thompson, our contracted supervisor during the construction/reclamation phase of the Sphinx Lake project. Alberta Environment's positive regulatory support for this project was crucial, particularly that of Ryan Puhlmann.

\section{References}

AENV (1999) Alberta Environment. Surface water quality guidelines for use in Alberta.

Anderson, R.S. (1971) Crustacean plankton of 146 alpine and sub-alpine lakes and ponds in western Canada. Journal of Fisheries Research Board Canada, Vol. 28, pp. 311-321.

Beckingham, J.D., Corns, I.G.W. and Archibald, J.H. (1996) Field guide to ecosites of west-central Alberta, Natural Resources Canada, Canadian Forest Service, Northern Forestry Centre, Edmonton, Alberta, Special Report 9.

Boorman, R. (2006) Seasonal limnological surveys of five end pit lakes on the Cardinal River Operations Mine Lease, 2005-2006, Prepared for Teck Cardinal River Operations by Pisces Environmental Services Ltd., 34 pp +App. 
CCME (2003) Canadian Council of Ministers of the Environment. Canadian environmental quality guidelines: water quality guidelines for the protection of aquatic life, Ottawa, ON.

CRO (2005) Cardinal River Operations. Proposal for an end pit lake monitoring program for the Luscar Mine.

EPLWG (2003) End Pit Lake Working Group Guidelines for lake development at coal mining operations in the mountains and foothills of the northern east slopes, Report \#ESD/LM/00-1, Alberta Environment, Environmental Service, Edmonton, AB, 89 p.

Mayhood, D.W. and Anderson, R.S. (1976) Limnological survey of the Lake Louise area, Banff National Park, Prepared for Parks Canada by the Canadian Wildlife Service, Calgary, AB.

Pisces Environmental Consulting Services Ltd (2009) Sphinx Lake monitoring in 2008, Prepared for Teck Cardinal River Operations by Pisces Environmental Services Ltd.

Pisces Environmental Consulting Services Ltd (2008) Sphinx Lake monitoring in 2007, Prepared for Teck Cardinal River Operations by Pisces Environmental Services Ltd.

Rasmussen, J., Peterson, S., Lele, S. and Rosenfeld, J. (2009) Report to the selenium working group on the selenium fish science panel (SeFSP) workshop, October 9-11, 2007, Hinton, AB.

Rexstad, E. and Burnham, K.P. (1992) User's guide for interactive program CAPTURE, Colorado State University, Fort Collins, CO, 29 p.

Ricker, W.E. (1975) Computation and interpretation of biological statistics of fish populations, Fisheries Research Board of Canada, Bulletin 191.

Schwartz, T. (2002) Fish populations, biomass and growth in Lac Des Roches, Alberta, Prepared for Cardinal River Coals Ltd by Pisces Environmental Services Ltd.

Thompson, G.E. (1978) Limnology of high mountain lakes in Kananaskis Country, Alberta Fish \& Wildlife Division, Calgary AB, $151 \mathrm{pp}$. 